\title{
Applying Cheerful Disco Learning for Improving of Motivation and Learning Result of PKn in Grade VIII C Students Junior High School 1 Kebumen in Second Semester 2013/2014 Academic Years

\author{
Siti Makmuroh \\ SMP Negeri I Kebumen \\ simakmur638@gmail.com
}

\begin{abstract}
The aim of this classroom action research is to improve students' learning motivation, learning result of PKn on Basic Competence of Describing Indonesian Government System and the Roles of the State Institutions as the Sovereignty Executive and the characters of Grade VIII C Students of Junior High School 1 of Kebumen in Second Semester of Academic Year 2013/2014 by applying CHEERFUL DISCO learning method. The research is a classroom action research conducted in two cycles; each cycle of which includes planning, conducting, observation, and reflection. The result of the research shows that the learning method was able to improve the students' learning motivation in learning activities from $62.37 \%$ in pre cycle to $73.74 \%$ in the first cycle, then from $78.91 \%$ in the second cycle, improved the PKn learning achievement in mastering concept of the ability to describe Indonesian Government System and the Roles of the State Institutions as the Sovereignty Executive, which can be seen that the students' achievement test result is improving in average from 78.18 with $54.55 \%$ of mastery learning in pre cycle to 83.23 with $72.73 \%$ of mastery learning in the first cycle, then it was improved to 86.59 in average with $81.82 \%$ of mastery learning in the second cycle.
\end{abstract}

Keywords: Cheerful Disco method, Learning Motivation, Learning Result.

\section{Pendahuluan}

Mata pelajaran

Pendidikan

Kewarganegaraan (PKn) merupakan satusatunya mata pelajaran yang memiliki peran yang sangat strategis dalam rangka menyukseskan pendidikan budaya dan karakter bangsa. Untuk itu, guru PKn dituntut mengembangkan pembelajaran yang bermutu agar siswa dapat menguasai konsep (civic knowledge) dan memiliki karakter (kepribadian) sesuai Standar Kompetensi Lulusan mata pelajaran ini.

Persoalan pembelajaran PKn yang ada pada kelas VIII C SMP Negeri 1 Kebumen tahun pelajaran 2013/2014 semester 2 adalah masih kurangnya motivasi belajar siswa dalam belajar PKn dan kurang optimalnya hasil belajar siswa. Yamin (2010, p. 219) menyatakan bahwa motivasi belajar merupakan daya penggerak psikis dalam diri seseorang untuk dapat melakukan kegiatan belajar dan menambah keterampilan serta pengalaman. Teori motivasi yang sekarang banyak dianut orang adalah teori kebutuhan dari Abraham Maslow yang beranggapan bahwa tindakan manusia pada hakikatnya adalah untuk memenuhi kebutuhannya, baik kebutuhan fisik maupun kebutuhan psikis. Kebutuhan akan aktualisasi diri, misalnya mempertinggi potensi-potensi yang dimiliki, pengembangan diri secara maksimal, Kreatifitas, dan ekspresi diri.

Motivasi belajar PKn merupakan sesuatu dalam diri seseorang yang mendorong dan mengarahkan serta memberi kekuatan kepada orang tersebut untuk melakukan suatu aktivitas belajar PKn dalam rangka memenuhi kebutuhannya. Dengan demikian siswa yang memiliki motivasi belajar PKn tentu akan terdorong untuk aktif dalam kegiatan pembelajaran PKn, baik secara fisik maupun psikis dalam rangka untuk mencapai 
tujuan belajarnya. Strategi yang dapat dilakukan oleh guru dalam menumbuhkan motivasi belajar siswa menurut Yamin (2011, pp. 236-256) antara lain 1) Menjelaskan tujuan pembelajaran kepada siswa, 2) Memberikan hadiah dan pujian, 3) Memberikan hukuman, 4) Menciptakan kompetisi, 5) Membentuk kebiasaan belajar yang baik, 6) Membangkitkan dorongan belajar, 7) Membantu kesulitan belajar siswa secara individu maupun kelompok, 8) Menggunakan metode yang bervariasi, 9) Menggunakan media yang sesuai dengan tujuan pembelajaran.

Hasil belajar dipengaruhi oleh banyak faktor. Secara umum, hasil belajar dipengaruhi oleh dua faktor, yaitu faktor dari dalam diri siswa dan faktor yang datang dari luar diri siswa atau lingkungan. Faktor dalam diri siswa terutama menyangkut kemampuan, motivasi belajar, minat dan perhatian, sikap dan kebiasaan belajar, ketekunan, sosial ekonomi, faktor fisik, dan psikis. (Sudjana, 2013, p. 39). Faktor di luar diri siswa yang mempengaruhi hasil belajar dapat berupa kualitas proses pembelajaran di sekolah, ketersediaan sarana pembelajaran, dukungan orang tua, dan lingkungan sosial pergaulan siswa. Di antara berbagai faktor di luar diri siswa yang paling berpengaruh adalah kualitas pengajaran. Kualitas pengajaran dipengaruhi oleh kualifikasi dan Kreatifitas guru, besarnya kelas, suasana belajar, fasilitas dan sumber belajar yang tersedia, serta tingkat kesulitan kompetensi atau materi pembelajaran. Kualitas pengajaran yang baik dapat meningkatkan motivasi belajar siswa yang akhirnya meningkatkan hasil belajarnya. Oleh karena itu guru harus merancang pembelajaran yang tepat agar pelaksanaan pembelajaran berkualitas.
Secara garis besar, hasil pembelajaran meliputi tiga jenis, yaitu kognitif, afektif, dan psikomotor. Ketiga jenis hasil belajar tersebut dijabarkan dalam bentuk taksonomi, artinya memiliki tingkatan-tingkatan dan setiap tingkatan memiliki ciri khas tersendiri sebagaimana menurut taksonomi Bloom dan revisinya oleh Anderson (2010).

Badan standar Nasional Pendidikan (BSNP) menggolongkan hasil belajar mata pelajaran Pendidikan Kewarganegaraan (PKn) menjadi tiga aspek, yaitu (1) pemahaman akan hak dan kewajiban diri sebagai warga negara atau aspek kognitif, (2) kepribadian, yaitu beberapa aspek kepribadian sebagaimana disebutkan dalam Kerangka Dasar dan Struktur Kurikulum, dan (3) perilaku kepribadian, yaitu berbagai bentuk perilaku sebagai penerjemahan dimilikinya ciri-ciri kepribadian warga negara Indonesia (Badan Standar Nasional Pendidikan, 2007, p. 10). Penelitian ini dilakukan pada hasil belajar aspek kognitif dengan indikator siswa memiliki pengetahuan dan pemahaman yang baik tentang materi pembelajaran, dapat memberi contoh penerapan materi pembelajaran tersebut dalam kehidupan nyata, dan dapat membuat kesimpulan terkait permasalahan yang berkaitan dengan materi pembelajaran.

Salah satu faktor penting yang menentukan keberhasilan proses pembelajaran adalah pemanfaatan model pembelajaran yang tepat. Pembelajaran Disco Ceria merupakan penerapan model pembelajaran Discovery yang dilakukan dengan teknik yang menimbulkan keceriaan peserta didik selama proses pembelajaran. Misalnya dengan teknik joint card, mencari pasangan, tempel pajangan, teka teki silang, kata bermakna, tim ahli, dll. Model pembelajaran discovery merupakan konsep 
pembelajaran penemuan yang dikembangkan oleh Jerome Bruner. Discovery learning berpijak dari teori belajar constructivism yang berpendapat bahwa belajar adalah suatu proses aktif dimana siswa membangun (mengkonstruksi) pengetahuan baru berdasarkan pengetahuan/pengalaman yang sudah dimilikinya. Menurut Dahar (dalam Trianto, 2011, p. 38), Jerome Bruner dengan teori penemuannya mengatakan bahwa belajar penemuan (discovery) sesuai dengan pencarian pengetahuan secara aktif oleh manusia dengan sendirinya akan memberi hasil yang paling baik, karena berusaha sendiri untuk mencari pemecahan masalah serta pengetahuan yang menyertainya, menghasilkan pengetahuan yang benar-benar bermakna. Pada discovery learning lebih ditekankan pada ditemukannya konsep atau prinsip yang sebelumnya tidak diketahui oleh siswa. Dalam discovery learning bahan ajar tidak disajikan dalam bentuk akhir, siswa dituntut untuk menghimpun informasi, membandingkan, mengkategorikan, menganalisis, mengintegrasikan bahan, serta membuat kesimpulan-kesimpulan. Dengan demikian model pembelajaran penemuan akan dapat membentuk kebiasaan belajar yang baik. Dalam mengaplikasikan model discovery learning di kelas, ada beberapa prosedur yang harus dilaksanakan dalam kegiatan pembelajaran, secara umum yaitu 1)

\section{Stimulation}

rangsangan), 2) Problem statement (pernyataan/ identifikasi masalah), 3) Data collection (pengumpulan data), 4) Data processing (pengolahan data), 5) Verification (pembuktian), 6) Generalization (menarik kesimpulan/generalisasi).

Proses pembelajaran yang menciptakan keceriaan pada peserta didik menjadikan peserta didik tidak mengalami kebosanan selama proses pembelajaran. Tidak jenuh, tidak kaku, dan menumbuhkan motivasi untuk mengikuti pembelajaran PKn. Motivasi merupakan salah satu faktor yang mempengaruhi hasil belajar peserta didik.

Kurangnya motivasi khususnya pada Kompetensi Dasar Mendeskripsikan Sistem Pemerintahan Indonesia dan Peran LembagaLembaga Negara Sebagai Pelaksana Kedaulatan Rakyat. Hasil ulangan siswa VIII C pada materi tersebut pada pra siklus mendapat nilai rata-rata masih belum sesuai harapan. Pada hasil penilaian awal, dari 22 siswa di kelas VIII C, yang mencapai tuntas belajar berdasarkan Kriteria Ketuntasan Minimal (KKM) SMP Negeri 1 Kebumen baru 12 (dua belas) siswa $(54,55 \%)$ dengan nilai rata-rata 78,18 . Untuk karakter atau kepribadian siswa kurang ditumbuhkan dalam proses pembelajaran.

Kemampuan siswa dalam mendeskripsikan Sistem Pemerintahan Indonesia dan Peranan Lembaga Negara sebagai Pelaksana Kedaulatan Rakyat perlu ditingkatkan. Hal ini sangat penting karena pemahaman yang baik dan benar tentang sistem pemerintahan Indonesia peran lembaga-lembaga negara dapat menumbuhkan kesadaran siswa bahwa sistem pemerintahan dan peran lembaga-lembaga negara yang telah dipercaya dan diberi amanah oleh rakyat harus dapat melaksanakan tugas, wewenang, hak dan kewajibannya sebagaimana ketentuan konstitusi negara.

Dalam pembelajaran PKn guru masih menggunakan metode konvensional yaitu metode ceramah dan tanya jawab. Penyampaian materi sangat verbalistis dan peran guru sangat dominan. Guru belum menerapkan metode yang mengaktifkan siswa dalam pembelajaran yang bertujuan 
untuk meningkatkan motivasi siswa agar menemukan sendiri pengetahuan melalui belajar kelompok (cooperative learning) dengan melakukan aktivitas yang bervariasi yaitu mengamati, mengumpulkan informasi, menyimpulkan, dan mengomunikasikan hasil belajarnya, sehingga siswa lebih memahami pengetahuan yang diperolehnya.

Guru menyadari faktor motivasi belajar mempunyai peranan yang amat penting dalam diri siswa untuk meningkatkan prestasi belajarnya. Rendahnya motivasi belajar siswa sehingga menyebabkan kurang optimalnya hasil belajar melahirkan keprihatinan guru. Keprihatinan tersebut disikapi oleh guru dengan berusaha memperbaiki proses pembelajaran dengan menerapkan model pembelajaran Disco Ceria dan mengaplikasikanya dalam bentuk Penelitian Tindakan Kelas (PTK), yang pelaksanaannya dilakukan dalam 2 (dua) siklus. Rumusan masalah yang diajukan dalam penelitian ini adalah 1) Apakah penerapan pembelajaran Disco Ceria dapat meningkatkan motivasi belajar PKn siswa kelas VIII C SMP Negeri 1 Kebumen semester 2 tahun pelajaran 2013/2014?, dan 2) Apakah penerapan pembelajaran Disco Ceria dapat meningkatkan hasil belajar siswa dalam kemampuan mendeskripsikan Sistem Pemerintahan Indonesia dan Peran LembagaLembaga Negara Sebagai Pelaksana Kedaulatan Rakyat pada siswa kelas VIII C SMP Negeri 1 Kebumen semester 2 tahun pelajaran 2013/2014?

Penelitian dilakukan dengan tujuan umum untuk 1) Meningkatkan motivasi belajar PKn, dan 2) Meningkatkan hasil belajar siswa dalam kemampuan mendeskripsikan Sistem Pemerintahan Indonesia dan Peran Lembaga-Lembaga Negara Sebagai Pelaksana Kedaulatan Rakyat pada siswa kelas VIII C SMP Negeri 1 Kebumen semester 2 tahun pelajaran 2013/2014. Sedangkan tujuan khusus penelitian ini adalah 1) Meningkatkan motivasi belajar PKn, dan 2) Meningkatkan hasil belajar dalam kemampuan mendeskripsikan Sistem Pemerintahan Indonesia dan Peran Lembaga-Lembaga Negara Sebagai Pelaksana Kedaulatan Rakyat pada siswa kelas VIII C SMP Negeri 1 Kebumen semester 2 tahun pelajaran 2013/2014 melalui penerapan model pembelajaran Disco Ceria.

\section{Metode}

Penelitian tindakan kelas ini dilakukan di SMP Negeri 1 Kebumen Kabupaten Kebumen, khususnya di Kelas VIII C. SMP Negeri 1 Kebumen merupakan sekolah tempat peneliti bertugas. Sedangkan kelas VIII C adalah kelas yang motivasi belajar dan prestasi belajar PKn paling rendah diantara 4 kelas yang diajar oleh peneliti, khususnya pada kompetensi dasar Mendeskripsikan Sistem Pemerintahan Indonesia dan Peran Lembaga-lembaga Negara Sebagai Pelaksana Kedaulatan Rakyat. Waktu penelitian adalah semester 2 tahun pelajaran 2013/2014, tepatnya pada bulan Maret s.d Juni 2014. Sedangkan penyusunan dan penyelesaian laporan hasil penelitian dilaksanakan pada bulan Juni s.d Agustus 2015.

Sumber data yang digunakan dalam penelitian tindakan kelas ini adalah 1) Hasil tes prestasi belajar, 2) Hasil angket motivasi siswa dalam pembelajaran, 3) Hasil observasi aktivitas siswa selama proses pembelajaran, dan 4) catatan pembelajaran (learning log) dari siswa. Sedangkan Teknik dan alat pengumpulan data dilakukan dengan tes, observasi, dan angket. Untuk validasi data penelitian digunakan teknik triangulasi, dan Analisis data menggunakan teknik analisis 
deskriptif komparatif yaitu membandingkan rata-rata dan persentase terhadap berbagai data yang diperoleh, yang selanjutnya dipaparkan secara deskriptif. Penelitian Tindakan Kelas (PTK) ini dilaksanakan dengan desain model siklus (Arikunto, Suhardjono, \& Supardi, 2007, p. 16). Penelitian ini direncanakan dengan dua siklus. Setiap siklus berisikan 4 (empat) kegiatan utama, yaitu: (1) Rencana, yaitu tindakan apa yang akan dilakukan untuk merubah sikap perilaku (2) Tindakan, yaitu melaksanakan strategi sebagai tindakan perbaikan, (3) Observasi, yaitu mengamati proses dan hasil tindakan, dan (4) Refleksi, yaitu mengkaji, melihat dan mempertimbangkan hasil tindakan untuk melakukan revisi.

\section{Hasil dan Pembahasan}

Pembelajaran PKn di Kelas VIII C SMP Negeri Kebumen Kabupaten Kebumen pada semester 2 tahun pelajaran 2013/2014 dengan materi Sistem Pemerintahan Indonesia yang dilakukan dengan metode ceramah bervariasi ternyata kualitas pembelajarannya kurang menggembirakan, baik dari segi proses pembelajaran, maupun hasil pembelajaran konsep atau pengetahuan. Proses pembelajaran cenderung membosankan. Sebagian siswa cenderung kurang memperhatikan, pasif, dan menunjukkan kemalasan. Akibatnya motivasi belajar siswa rendah dan hasil belajar mendeskripsikan Sistem Pemerintahan Indonesia belum memuaskan karena KKM yang ditetapkan, yaitu 83 belum dapat tercapai. Rata-rata nilai tes hanya 78,18 dengan ketuntasan belajar siswa hanya mencapai $54,55 \%$. Artinya masih ada $45,45 \%$ atau 10 dari 12 siswa yang belum mencapai batas tuntas. Hasil pembelajaran yang belum memuaskan menjadikan semangat dan kepuasan guru dalam pembelajaran cenderung menurun. Untuk itu, diperlukan perbaikan pembelajaran sehingga mampu meningkatkan kualitas dan motivasi siswa agar hasil belajar dapat ditingkatkan, serta meningkatkan karakter atau kepribadian siswa. Perbaikan dilakukan dengan memperbaiki proses pembelajaran melalui penelitian tindakan kelas yang dilakukan dalam dua siklus.

Siklus pertama merupakan proses pembelajaran dengan materi Lembaga Negara Sebagai Pelaksana Kedaulatan Rakyat. Siklus pertama terdiri dari dua kali pertemuan masing-masing 2 x 40 menit. Langkah pokok dalam siklus pertama adalah sebagai berikut.

\section{a. Tahap Pendahuluan}

Dalam tahap pendahuluan ini Guru membuka pelajaran dengan salam dan doa, kemudian Guru mengecek kehadiran siswa. Guru memberikan motivasi dan apersepsi, kemudian menjelaskan tujuan pembelajaran, serta menjelaskan langkahlangkah pembelajaran Disco Ceria

\section{b. Kegiatan Inti}

Pada kegiatan ini pertama-tama Guru memberikan Overview/Pemberian rangsangan (stimulation) dengan cara menjelaskan materi-materi pokok melalui tayangan power point dan gambar-gambar yang relevan dengan materi pelajaran. Para siswa mencermati tayangan dan penjelasan dari guru secara seksama. Langkah berikutnya Guru mengajukan pertanyaan/ masalah (problem statement) yang sesuai dengan tujuan pembelajaran untuk dipecahkan atau ditemukan jawabannya oleh siswa melalui kerja kelompok. Guru membagi siswa menjadi empat kelompok, masing-masing kelompok beranggotakan 5 sampai 6 siswa. Kemudian masing-masing kelompok diberikan LKS oleh guru untuk 
penjawab pertanyaan atau mengerjakan tugas yang terkait dengan landasan hukum, pengisian keanggotaan dan kedudukan lembaga negara yang menjadi tanggung kelompoknya. Selanjutnya para siswa dalam kelompoknya berusaha menemukan jawaban atau solusi atas pertanyaan-pertanyaan masing-masing kelompok, dengan mencermati materi yang ada dalam buku PKn Kelas VIII Buku Sekolah Elektronik (BSE) Bab 5 dan naskah UUD 1945 hasil amandemen, atau sumber lain yang relevan. Kemudian Guru meminta siswa untuk menuliskan temuannya/jawabannya dalam LKS masing-masing dan mempresentasikan di depan kelas secara bergantian sesuai undian. Setelah semua kelompok melakukan presentasi, guru memberikan klarifikasi atas jawaban/hasil kerja kelompok siswa. Selanjutnya dibawah bimbingan guru, siswa membuat kesimpulan dan mencatat kesimpulan tersebut dalam buku catatan masingmasing.

\section{c. Kegiatan Penutup}

Pada kegiatan penutup Guru memberi tugas rumah secara individu agar setiap siswa membuat catatan harian yang berisi tentang apa yang telah dipelajari atau diperoleh dari kegiatan belajar PKn hari ini, kemudian Guru menginformasikan kegiatan dan materi pada pertemuan yang akan datang. Pada akhir pertemuan ke 2 guru melakukan tes (penilaian) untuk mengetahui hasil belajar siswa. Tidak lupa Guru melakukan refleksi dengan meminta siswa member kesan dan pesan terhadap proses pembelajaran. Dan terakhir Guru menutup pelajaran dengan salam dan doa tepat waktu.
Berdasarkan hasil pengamatan, proses pembelajaran berjalan efektif sesuai yang direncanakan guru dalam Rencana Pelaksanaan Pembelajaran (RPP). Aktivitas siswa dalam pembelajaran terjadi peningkatan dari $61 \%$ pada prasiklus menjadi $70 \%$ pada siklus I. Peningkatan aktivitas siswa menunjukkan adanya peningkatan motivasi karena motivasi mendorong seseorang untuk melakukan aktivitas. Hal ini sejalan dengan hasil angket motivasi siswa yang menunjukkan adanya peningkatan dari rata-rata 62,37 pada pra siklus menjadi 73,74 pada siklus I. Peningkatan aktivitas siswa yang merupakan indikasi dari adanya peningkatan motivasi diikuti dengan peningkatan prestasi belajar siswa. Peningkatan tersebut seperti terlihat dalam tabel sebagai berikut.

Tabel 1 Prestasi Belajar Siklus I

\begin{tabular}{clcc}
\hline No. & \multicolumn{1}{c}{ Aspek } & Jumlah & Ket. \\
\hline 1. & $\begin{array}{l}\text { Nilai rata-rata } \\
\text { penguasaan konsep }\end{array}$ & 83,23 & \\
2. & $\begin{array}{l}\text { Ketuntasan belajar } \\
\text { 5. }\end{array}$ & $\begin{array}{l}\text { Siswa dengan nilai } \\
\text { diatas KKM }\end{array}$ & 10 siswa \\
6. & $\begin{array}{l}\text { Siswa dengan nilai pada } \\
\text { batas KKM }\end{array}$ & 6 siswa & \\
7. & $\begin{array}{l}\text { Siswa dengan nilai } \\
\text { dibawah KKM }\end{array}$ & 6 siswa \\
\hline
\end{tabular}

Sumber: data diolah peneliti, 2017.

Siklus kedua merupakan proses pembelajaran pertemuan berikutnya dengan materi Peran Lembaga-Lembaga Negara Sebagai Pelaksana Kedaulatan Rakyat.Siklus II terdiri dari $2 \mathrm{x}$ pertemuan masing-masing 2 x 40 menit. Langkah pokok pembelajaran dalam siklus kedua adalah sebagai berikut.

\section{a. Tahap Pendahuluan}

Dalam tahap pendahuluan ini Guru membuka pelajaran dengan salam doa, mengecek kehadiran siswa, memberikan motivasi, memberikan apersepsi dan menjelaskan tujuan pembelajaran, serta 
menjelaskan

langkah-langkah

pembelajaran Disco Ceria .

\section{b. Kegiatan Inti}

Pada kegiatan ini pertama-tama guru memberikan

Overview/Pemberian

rangsangan (stimulation) dengan cara menjelaskan materi-materi pokok melalui tayangan power point dan gambar-gambar yang relevan dengan materi pelajaran Para siswa mencermati tayangan dan penjelasan dari guru secara seksama. Langkah selanjutnya guru mengajukan pertanyaan/masalah (problem statement) dengan membagikan 1 (satu) set kartu diskusi siswa kepada masing-masing kelompok yang berisi 5 (lima) masalah sesuai materi pokok. Kartu diskusi agar dibagikan kepada masing-masing anggota kelompoknya. Kartun diskusi nomor 1 berisi tentang materi terkait tugas dan wewenang lembaga negara. Selanjutnya Guru meminta siswa menyebar dan membentuk kelompok baru (kelompok ahli) sesuai dengan nomor masalah yang ada di kartu yang mereka terima. Guru meminta siswa dalam kelompok ahli mencermati pertanyaan/masalah yang harus dijawab atau dipecahkan oleh mereka dengan membaca materi yang ada dalam buku PKn Kelas VIII Bab 5 dan naskah UUD 1945 hasil amandemen atau sumber lain yang relevan. Setelah semua kelompok ahli menyelesaikan tugasnya, guru meminta semua peserta kembali ke kelompok asal. Guru meminta setiap peserta menyampaikan hasil diskusi dengan kelompok ahli kepada temantemannya di kelompok asal. Selanjutnya guru dibantu siswa membagikan 1 (satu) paket yang berisi potongan-potongan kertas tentang tugas, wewenang, atau fungsi lembaga-lembaga negara yang dipelajari siswa hari ini kepada setiap kelompok, kemudian guru mengarahkan agar hasil kerja seluruh anggota kelompok disatukan dan disusun menjadi sebuah laporan tugas kelompok dalam bentuk bagan dengan cara menempelkan potongan-potongan kertas yang telah diberikan oleh guru menjadi bentuk bagan yang menarik. Kelompok yang sudah selesai membuat bagan segera menempelkan hasil kerja kelompoknya pada tempat yang memungkinkan, selanjutnya guru mengecek dan memberikan klarifikasi atau penjelasan terkait pengetahuan yang ditemukan siswa dalam kerja kelompok. Dibawah bimbingan guru, kemudian para siswa membuat kesimpulan materi dan mencatat dalam buku catatan masing-masing.

\section{c. Penutup}

Guru menjelaskan kegiatan dan materi pada pertemuan yang akan datang yaitu mempresentasikan hasil kerja kelompok yang dilakukan hari ini. Pada akhir pertemuan ke 2 guru melakukan penilaian untuk mengetahui prestasi belajar siswa. Guru meminta kesan dan pesan dari siswa selama pelaksanaan pembelajaran. Kemudian guru menutup pelajaran dengan salam dan doa bersama tepat waktu.

Berdasarkan hasil pengamatan, proses pembelajaran berjalan efektif sesuai yang direncanakan guru dalam Rencana Pelaksanaan Pembelajaran (RPP). Aktivitas siswa dalam pembelajaran terjadi peningkatan dari $70 \%$ pada siklus pertama menjadi $77 \%$ pada siklus kedua. Peningkatan aktivitas siswa menunjukkan adanya peningkatan motivasi karena motivasi mendorong seseorang untuk melakukan aktivitas. Hal ini sejalan dengan hasil angket 
motivasi siswa yang menunjukkan adanya peningkatan dari 73,74 pada pra siklus pertama menjadi 78,91 pada siklus kedua. Peningkatan aktivitas siswa yang merupakan indikasi dari adanya peningkatan motivasi diikuti dengan peningkatan prestasi belajar. Prestasi belajar penguasaan konsep tentang Peran Lembaga-Lembaga Negara sebagai Pelaksana Kedaulatan Rakyat pada siklus kedua adalah sebagai berikut.

Tabel 2 Prestasi Belajar Siklus II

\begin{tabular}{llll}
\hline No. & Aspek & Jumlah & Ket. \\
\hline 1. & $\begin{array}{l}\text { Nilai rata-rata } \\
\text { penguasaan konsep }\end{array}$ & 86,59 & \\
2. & $\begin{array}{l}\text { Ketuntasan belajar } \\
81,82 \%\end{array}$ & 18 siswa \\
3. & $\begin{array}{l}\text { Siswa dengan nilai } \\
\text { diatas KKM }\end{array}$ & 14 siswa & \\
4. & $\begin{array}{l}\text { Siswa dengan nilai } \\
\text { pada batas KKM }\end{array}$ & 4 siswa & \\
5. & $\begin{array}{l}\text { Siswa dengan nilai } \\
\text { dibawah KKM }\end{array}$ & 4 siswa & \\
\hline
\end{tabular}

Sumber: data diolah peneliti, 2017.

Pada siklus pertama diskusi kelompok masih kurang mengena dan kurang fokus pada satu masalah karena diskusi kolaboratif masih umum. Siswa mendiskusikan masalahmasalah dengan kelompoknya sendiri sehingga pencapaian hasilnya belum optimal. Setiap kelompok hanya terpaku pada lembar tugas kelompok masing-masing secara kaku dan kurang adanya mobilitas dan kolaborasi. Kerja sama dalam kelompok masih kurang maksimal meskipun sudah ada peningkatan. Terlihat beberapa anggota kelompok masih pasif. Pada saat siswa diarahkan oleh guru menuliskan laporan hasil diskusi kelompok, hanya dua tiga siswa dalam kelompok yang terpantau aktif mengerjakan tugas tersebut sedangkan anggota yang lain cenderung pasif dan bahkan ada yang bermain atau mengobrol dengan teman. Pada presentasi hasil diskusi, siswa tampak masih kurang percaya diri karena hanya sebatas membaca yang ada dalam lembar tugas kelompok. Akibatnya, diskusi kelas dalam rangka memaparkan hasil penemuan yang dipandu dengan lembar diskusi kelompok masih kaku dan kolaborasi kelas kurang optimal.

Pada siklus kedua pembelajaran diawali dengan pembentukan kelompok, kemudian setiap siswa dalam kelompok diberikan kartu masalah yang harus diteliti dan diskusikan bersama siswa dari kelompok lain dengan nomor kartu masalah yang sama (membentuk kelompok ahli). Di sini sudah tampak jelas kolaboratifnya. Diskusi dalam kelompok dengan kartu yang sama semakin memfokuskan masalah sehingga cepat selesai dan hasilnya tampak lebih optimal. Setelah selesai dalam diskusi kelompok ahli (nomor kartu masalah homogen), siswa kembali ke kelompok asal dan menyampaikan hasilnya kepada teman-temannya di kelompok asal, untuk selanjutnya disusun laporan hasil diskusi dengan desain menata potonganpotongan kertas yang bertuliskan tugas, wewenang, ataupun fungsi lembaga-lembaga negara sehingga berbentuk bagan yang terlihat menarik. Diskusi kolaboratif siklus kedua benar-benar berjalan optimal sehingga pencapaian hasilnya pun menjadi optimal. Pada presentasi hasil diskusi, siswa lebih percaya diri karena hasil diskusi sudah disajikan dalam bentuk bagan yang lebih menarik dan mudah dipahami sehingga diskusi kelas dalam rangka memaparkan hasil penelitian berlangsung secara baik dengan kolaborasi kelas yang optimal.

Kurangnya kolaborasi dalam diskusi kelompok siklus pertama menyebabkan siswa kurang kompak dalam mendiskusikan masalah yang menjadi tanggung jawab kelompoknya dan diskusi masih berbentuk diskusi kelompok biasa, diperbaiki pada siklus kedua dengan diskusi dilakukan secara tim ahli. Dengan dikaji oleh ahlinya hasil 
kajian menjadi lebih optimal. Selain itu, lembar tugas kelompok ternyata belum mampu mendinamisasikan kelompok untuk secara intense mendiskusikan dan mengkaji masalah sehingga diperbaiki dengan menggunakan kartu masalah dalam diskusi di kelompok ahli dan diakhiri dengan membuat bagan.

Presentasi yang kurang optimal pada siklus pertama karena hanya terpancang pada lembar tugas kelompok diperbaiki dengan menyajikan laporan diskusi dalam bentuk bagan yang lebih menarik. Hal itu benarbenar mampu mendorong kreativitas siswa dan menjadikan diskusi kolaboratif kelas berjalan secara optimal. Perbaikan-perbaikan atas dasar refleksi secara kolaboratif membawa hasil yang positif karena mampu meningkatkan motivasi, kualitas proses dan hasil pembelajaran, baik penguasaan konsep maupun karakter atau kepribadian siswa (tanggung jawab, percaya diri, saling menghargai, kerja sama, dan kompetitif).

Berdasarkan tujuan, hipotesis, dan indikator kinerja Penelitian Tindakan Kelas ini menunjukkan hasil peningkatan Motivasi dan hasil belajar Siswa. Penerapan pembelajaran Disco Ceria dalam pembelajaran $\mathrm{PKn}$ mampu meningkatkan motivasi siswa dalam pembelajaran. Peningkatan motivasi siswa dapat diketahui dari hasil pengamatan terhadap aktivitas siswa selama proses pembelajaran, karena aktivitas dapat menjadi indikasi adanya motivasi dalam diri siswa untuk melakukan tindak belajar, sebab motivasi mendorong seseorang unruk bertindak dalam rangka mencapai tujuan atau memenuhi kebutuhannya. Selain itu peningkatan motivasi siswa juga dapat diketahui dari hasil angket motivasi yang diisi oleh siswa. Peningkatan aktivitas siswa dalam pembelajaran dapat dilihat pada tabel di bawah ini.

Tabel 3 Peningkatan Aktivitas Siswa dalam Pembelajaran

\begin{tabular}{|c|c|c|c|}
\hline No & Siklus & $\%$ & Keterangan \\
\hline 1. & Prasiklus & $61.00 \%$ & $\begin{array}{c}\text { Indikator kinerja } \\
\quad(>75)\end{array}$ \\
\hline 2. & Siklus I & $70.00 \%$ & $\begin{array}{l}\text { Indikator kinerja } \\
\qquad(>75) \text {, } \\
\text { belum tercapai }\end{array}$ \\
\hline 3. & Siklus II & $77.00 \%$ & $\begin{array}{c}\text { Indikator kinerja } \\
\quad(>75) \text {, } \\
\text { sudah tercapai }\end{array}$ \\
\hline
\end{tabular}

Sumber: data diolah peneliti, 2017.

Sedangkan peningkatan motivasi siswa dilihat dari hasil angket motivasi adalah sebagai berikut.

Tabel 4 Peningkatan Motivasi Siswa Berdasar Hasil Angket

\begin{tabular}{llcl}
\hline No. & Siklus & $\begin{array}{c}\text { Rata-rata } \\
(\%)\end{array}$ & \multicolumn{1}{c}{ Keterangan } \\
\hline 1. & Prasiklus & $62.37 \%$ & $\begin{array}{l}\text { Indikator kinerja } \\
(>75)\end{array}$ \\
2. & Siklus I & $73.74 \%$ & $\begin{array}{l}\text { Indikator kinerja } \\
(>75) \\
\text { belum tercapai }\end{array}$ \\
3. & Siklus II & & $\begin{array}{l}\text { Indikator kinerja } \\
(>75) \\
\text { sudah tercapai }\end{array}$ \\
\hline
\end{tabular}

Sumber: data diolah peneliti, 2017.

Berdasarkan tabel di atas hipotesis tindakan yang menyatakan bahwa penerapan model pembelajaran Disco Ceria dapat meningkatkan motivasi belajar siswa Kelas VIII C SMP Negeri 1 Kebumen Kabupaten Kebumen semester 2 tahun pelajaran 2014/2015 terbukti kebenarannya, indikator kinerja telah tercapai atau terpenuhi setelah siklus II.

Hasil belajar penguasaan konsep pada Kompetensi Dasar mendeskripsikan Sistem Pemerintahan Indonesia dan Peran LembagaLembaga Negara Sebagai Pelaksana Kedaulatan Rakyat yang dilakukan dengan menerapkan pembelajaran Disco Ceria menjadi lebih meningkat. Hal itu tampak dari nilai rata-rata prestasi belajar penguasaan 
konsep dan persentase ketuntasan belajar yang pada kondisi awal belum mampu mencapai ketuntasan belajar, namun pada akhir siklus II mayoritas siswa dapat mencapai ketuntasan belajar. Rata-rata hasil tes juga mengalami peningkatan secara signifikan. Peningkatan prestasi belajar dan ketuntasan belajar siswa dalam mendeskripsikan Sistem Pemerintahan Indonesia dan Peran Lembaga-Lembaga Negara Sebagai Pelaksana Kedaulatan Rakyat dapat dilihat pada tabel sebagai berikut.

Tabel 5 Peningkatan Prestasi Belajar Siswa

\begin{tabular}{|c|c|c|c|c|}
\hline No & Siklus & $\begin{array}{c}\text { Nilai } \\
\text { rata-rata }\end{array}$ & $\begin{array}{c}\text { Ketuntasan } \\
\text { Belajar }\end{array}$ & Keterangan \\
\hline 1. & $\begin{array}{l}\text { Pra } \\
\text { siklus }\end{array}$ & 78.18 & $54.55 \%$ & $\begin{array}{l}\text { Indikator kinerja } \\
\text { rata-rata } 85 \text { dengan } \\
\text { ketuntasan }>80 \%\end{array}$ \\
\hline 2. & $\begin{array}{l}\text { Siklus } \\
\text { I }\end{array}$ & 83,23 & $72.73 \%$ & $\begin{array}{l}\text { Indikator kinerja } \\
\text { rata-rata } 85 \text { dengan } \\
\text { ketuntasan }>80 \% \\
\text { : belum tercapai }\end{array}$ \\
\hline 3. & $\begin{array}{l}\text { Siklus } \\
\text { II }\end{array}$ & 86.59 & $81.82 \%$ & $\begin{array}{l}\text { Indikator kinerja } \\
\text { rata-rata } 85 \text { dengan } \\
\text { ketuntasan }>80 \% \\
\text { : sudah tercapai }\end{array}$ \\
\hline
\end{tabular}

Sumber: data diolah peneliti, 2017.

Berdasarkan tabel di atas hipotesis tindakan yang menyatakan bahwa penerapan model pembelajaran discovery dapat meningkatkan prestasi belajar tentang PKn materi Sistem Pemerintahan Indonesia dan Peran Lembaga-Lembaga Negara Sebagai Pelaksana Kedaulatan Rakyat pada siswa Kelas VIII C SMP Negeri 1 Kebumen Kabupaten Kebumen semester 2 tahun pelajaran 2014/2015 terbukti kebenarannya, indikator kinerja penelitian, yaitu meningkatnya rata-rata prestasi belajar PKn mencapai di atas KKM (85) dan siswa yang tuntas belajar mencapai lebih dari $80 \%$ juga sudah tercapai pada akhir siklus II.

\section{Simpulan}

Berdasar analisis data, temuan, dan pembahasan pada Bab IV dapat disimpulkan bahwa penerapan pembelajaran Disco Ceria berhasil meningkatkan motivasi dan hasil belajar PKn pada Kompetensi Dasar Mendeskripsikan Sistem Pemerintahan Indonesia dan Peran Lembaga-Lembaga Negara Sebagai Pelaksana Kedaulatan Rakyat, serta meningkatkan karakter atau kepribadian siswa kelas VIII C SMP Negeri 1 Kebumen Kabupaten Kebumen semster 2 tahun pelajaran 2013/2014. Keberhasilan tindakan ini dapat diketahui dari hal-hal sebagai berikut.

1. Peningkatan motivasi belajar siswa.

Berdasarkan hasil pengamatan terhadap aktivitas siswa dalam pembelajaran terjadi peningkatan dari $61 \%$ pada prasiklus menjadi $70 \%$ pada siklus I, kemudian menjadi $77 \%$ pada siklus II. Sedangkan berdasarkan hasil angket motivasi terjadi peningkatan dari $62,37 \%$ pada prasiklus menjadi $73,74 \%$ pada siklus I, kemudian menjadi $78,91 \%$ pada siklus II.

2. Peningkatan hasil belajar

Berdasarkan hasil ulangan harian siswa terjadi peningkatan nilai rata-rata dari 78,18 pada prasiklus menjadi 83,23 pada siklus I, kemudian menjadi 86,59 pada siklus II. Sedangkan ketercapaian KKM juga terjadi peningkatan dari 54,55\% pada 
prasiklus menjadi $72,73 \%$ pada siklus I, kemudian menjadi $81,82 \%$ pada siklus II. Berdasarkan kesimpulan di atas, diberikan saran-saran sebagai berikut.

1. Proses pembelajaran hendaknya menggunakan variasi model atau strategi dan media yang tepat agar benar-benar mampu mengaktifkan siswa secara kolaboratif sehingga mampu meningkatkan motivasi dan prestasi belajar serta terbentuknya karakter siswa.

2. Integrasi pendidikan karakter agar dilakukan secara terencana dan terobservasi secara objektif sehingga efektif membentuk kepribadian siswa.

3. Bagi guru PKn yang akan mengadopsi model pembelajaran ini perlu mempersiapkan seluruh sarana dan prasarana pembelajaran agar berjalan dan berhasil secara optimal.

4. Bagi siswa perlu dikondisikan kesadaran dan pemahamannya tentang diskusi kolaboratif dalam memecahkan suatu masalah agar semua siswa benar-benar terlibat dan memahami materi pembelajaran.

\section{Daftar Pustaka}

Anderson, L. W., \& Krathwol, D. R. (Eds.). (2010). Kerangka landasan pembelajaran, pengajaran dan asesmen. Yogyakarta: Pustaka Pelajar.

Arikunto, S., Suhardjono, \& Supardi. (2007). Penelitian tindakan kelas. Jakarta: Sinar Grafika.

Badan Standar Nasional Pendidikan. (2007). Panduan penilaian kelompok mata pelajaran kewarganegaraan dan kepribadian. Jakarta: Badan Standar Nasional Pendidikan Departemen Pendidikan Nasional.

Martinis, Y. (2010). Kiat membelajarkan siswa. Jakarta: Gaung Persada Press dan Center for Learning Innovation (CLI).

Sudjana, N. (2013). Dasar-dasar proses belajar mengajar. Bandung: Sinar Baru Algensindo.

Trianto. (2011). Mendesain model pembelajaran inovatif-progresif. Jakarta: Kencana Prenada Media.

Yamin, M. (2011). Paradigma baru pembelajaran. Jakarta: Gaung Persada Press. 